Journal Indonesian Language Education and Literature Vol.1, No. 2, 2016

http://www.syekhnurjati.ac.id/jurnal/index.php/jeill/

\title{
PENERAPAN TEORI KONSTRUKTIVISTIK \\ PADA PEMBELAJARAN BAHASA ARAB DI IAIN SYEKH NURJATI CIREBON
}

\author{
Hikmah Uswatun Ummi, Indrya Mulyaningsih \\ hikmah.uu@gmail.com
}

\begin{abstract}
Abstrak
Metode mengajar digunakan sesuai kreativitas guru. Pembelajaran bahasa asing khususnya bahasa Arab di Program Intensifikasi Bahasa Arab IAIN Syekh Nurjati Cirebon menggunakan berbagai macam metode. Metode inquiry, tanya jawab, dan kelompok merupakan metode mengajar menurut pendekatan konstruktivistik. Teori konstruktivistik memahami belajar sebagai proses pembentukan (konstruksi) pengetahuan oleh pembelajar itu sendiri. Ketertarikan terhadap teori konstruktivistik mendorong penulis untuk mengamati penerapan teori konstruktivistik di kelompok 28 Program Intensifikasi Bahasa Arab IAIN Syekh Nurjati Cirebon. Hasil observasi menyatakan bahwa pembelajaran bahasa Arab di kelompok 28 Program Intensifikasi Bahasa Arab IAIN Syekh Nurjati Cirebon menggunakan pendekatan teori kontruktivisme.

Use appropriate teaching methods teachers' creativity. Learning foreign languages, especially Arabic Arabic Intensification Program IAIN Sheikh Nurjati Cirebon using various methods. Method of inquiry, question and answer, and the group is a method of teaching according to the constructivist approach . Constructivist theory of learning understood as the process of formation (construction) knowledge by the learners themselves. Interest in constructivist theory encourages authors to observe the application of constructivist theory in a group of 28 Intensification Program Arabic IAIN Sheikh Nurjati Cirebon. Results observation is that the Arabic language learning in a group of 28 Intensification Program Arabic IAIN Sheikh Nurjati Cirebon approach constructivism theory .
\end{abstract}

Kata kunci: belajar, bahasa, konstruktivistik, teori

\section{A. Pendahuluan}

Tujuan lembaga pendidikan bukan hanya mentransfer ilmu pengetahuan tetapi juga harus menciptakan lingkungan dan pengalaman siswa untuk dapat menemukan dan mengkonstruksi pengetahuan. Lembaga pendidikan harus memfasilitasi siswa agar mampu menemukan, merumuskan dan menyelesaikan masalah. Begitupun dengan pembelajaran bahasa. Hal ini sesuai dengan teori konstruktivisme yang membiarkan siswa menemukan pengetahuan (metode inkuiri) sedangkan peran pendidik sebagai fasilitator, 
pengarah, dan penuntun siswa. Pada praktiknya, teori tersebut tidak selalu diterapkan pada kegiatan pembelajaran bahasa karena penggunaan metode bergantung pada keterampilan pengajar.

Pembelajaran bahasa asing khususnya bahasa Arab di Program Intensifikasi Bahasa Arab IAIN Syekh Nurjati Cirebon menggunakan berbagai macam metode. Ketertarikan terhadap teori konstruktivistik mendorong penulis untuk mengamati penerapan teori konstruktivistik di kelompok 28 Program Intensifikasi Bahasa Arab IAIN Syekh Nurjati Cirebon.

Adapun rumusan masalah artikel ini adalah "Bagaimana penerapan teori konstruktivistik pada pembelajaran bahasa Arab di kelompok 28 Program Intensifikasi Bahasa Arab IAIN Syekh Nurjati Cirebon?"

Teori konstruktivisme memahami belajar sebagai proses pembentukan (konstruksi) pengetahuan oleh pembelajar itu sendiri. Menurut pandangan konstruktivisme, belajar merupakan suatu proses pembentukan pengetahuan. Berikut ini, beberapa definisi teori konstruktivisme dari beberapa ahli (Lamijan, 2015):

a. Jean Piaget menyatakan bahwa pengetahuan yang diperoleh seorang anak merupakan hasil dari konstruksi pengetahuan awal yang telah dimiliki dengan pengetahuan yang baru diperolehnya

b. Lev Vygotsky berkata ada dua konsep penting dalam teori Vygotsky yaitu. (1) Zone of Proximal Development (ZPD), Kemampuan pemecahan masalah di bawah bimbingan orang dewasa atau melalui kerjasama dengan teman sejawat yang lebih mampu; dan (2) Scaffolding, pemberian sejumlah bantuan kepada siswa selama tahap-tahap awal pembelajaran, kemudian mengurangi bantuan dan memberikan kesempatan untuk mengambil alih tanggung jawab yang semakin besar setelah ia dapat melakukannya

c. John Dewey bahwa belajar bergantung pada pengalaman dan minat siswa sendiri dan topik dalam Kurikulum harus saling terintegrasi bukan terpisah atau tidak mempunyai kaitan satu sama lain. Belajar harus bersifat 
Journal Indonesian Language Education and Literature Vol.1, No. 2, 2016

http://www.syekhnurjati.ac.id/jurnal/index.php/jeill/

aktif,langsung terlibat, berpusat pada Siswa $(\mathrm{SCL}=$ Student Centered Learning) dalam konteks pengalaman sosial.

Berikut ini ciri-ciri belajar berbasis konstruktivisme menurut Driver dan Oldham (1994):

a. Orientasi, yaitu siswa diberi kesempatan untuk mengembangkan motivasi dalam mempelajari suatu topic dan memberikan kesempatan melakukan observasi.

b. Elisitasi, yaitu mengungkapkan idenya dengan jalan berdiskusi menulis, membuat poster dan lain-lain.

c. Restrukturisasi ide, yaitu klasifikasi ide dengan ide orang lain dengan membuat ide baru, mengevaluasi ide baru.

d. Penggunaan ide baru dalam berbagai situasi, yaitu ide atau pengetahuan yang telah terbentuk perlu diaplikasikan pada berbagai macam situasi.

e. Review, yaitu mengaplikasikan pengetahuan, gagasan yang ada perlu direvisi dengan menambahkan atau mengubah.

Von Glaserfed (dalam Paul, 1996), mengemukakan bahwa beberapa kemampuan yang diperlukan dalam proses mengonstruksi pengetahuan, yaitu:

a. Kemampuan mengingat dan mengungkapkan kembali pengalaman.

b. Kemampuan membandingkan dan mengambil keputusan mengenai persamaan dan perbedaan tentang suatu hal.

c. Kemampuan untuk lebih menyukai suatu pengalaman yang satu daripada yang lain (selective conscience).

Faktor-faktor yang membatasi proses konstruksi pengetahuan adalah:

a. Hasil konstruksi yang telah dimiliki seseorang (constructed knowledge).

b. Domain pengalaman seseorang (domain of experience).

c. Jaringan struktur kognitif seseorang (existing cognitive structure).

Peranan guru pada pendekatan konstruktivisme, yang meliputi kegiatan-kegiatan sebagai mediator dan fasilitator bagi siswa: 
a. Menyediakan pengalaman belajar agar siswa bertanggungjawab.

b. Menyediakan atau memberikan kegiatan-kegiatan yang merangsang keingintahuan siswa dan membantu mereka untuk mengekspresikan gagasannya.

c. Memonitor, mengevaluasi, dan menunjukkan apakah pemikiran siswa berjalan atau tidak.

Beberapa hal penting tentang evaluasi dalam aliran kontruktivistik, adalah:

a. Diarahkan pada tugas-tugas autentik;

b. Mengkonstruksi pengetahuan yang menggambarkan proses berpikir yang lebih tinggi

c. Mengkontruksi pengalaman siswa; dan

d. Mengarahkan evaluasi pada konteks yang luas dengan berbagai perspektif.

Pembelajaran kontruktivistik membantu siswa menginternalisasi dan mentransformasi informasi baru.Perbedaan karakteristik antara pembelajaran tradisional (behavioristik) dengan pembelajaran konstruktivisme, adalah sebagai berikut.

\begin{tabular}{|l|l|}
\hline \multicolumn{1}{|c|}{ Pembelajaran Tradisional } & \multicolumn{1}{|c|}{ Pembelajaran Konstruktivisme } \\
\hline $\begin{array}{l}\text { 1.Kurikulum disajikan dari bagian-bagian } \\
\text { menuju keseluruhan dengan menekankan } \\
\text { pada keterampilan-keterampilan dasar. }\end{array}$ & $\begin{array}{l}\text { 1.Kurikulum disajikan mulai dari } \\
\text { keseluruhan menuju kebagian-bagian, dan } \\
\text { lebih mendekatkan pada konsep-konsep } \\
\text { yang lebih luas. }\end{array}$ \\
\hline $\begin{array}{l}\text { 2.Pembelajaran sangat taat pada kurikulum } \\
\text { yang telah ditetapkan. }\end{array}$ & $\begin{array}{l}\text { 2.Pembelajaran lebih menghargai pada } \\
\text { pemunculan pertanyaan dan ide-ide siswa. }\end{array}$ \\
\hline $\begin{array}{l}\text { 3.Kegiatan kurikuler lebih banyak } \\
\text { mengandalkan pada buku teks dan buku } \\
\text { kerja }\end{array}$ & $\begin{array}{l}\text { 3.Kegiatan kurikuler lebih banyak } \\
\text { mengandalkan pada sumber-sumber data } \\
\text { primer dan manipulasi bahan. }\end{array}$ \\
\hline $\begin{array}{l}\text { 4.Siswa dipandang sebagai: "kertas kosong" } \\
\text { yang dapat digoresi informasi oleh guru, dan } \\
\text { guru-guru pada umumnya menggunakan cara } \\
\text { didaktik dalam menyampaikan informasi } \\
\text { kepada siswa }\end{array}$ & $\begin{array}{l}\text { 4.siswa dipandang sebagai pemikir yang } \\
\text { dapat memunculkan teori-teori tentang } \\
\text { dirinya. }\end{array}$ \\
\hline $\begin{array}{l}\text { 5.Penilaian hasil belajar atau pengetahuan } \\
\text { siswa dipandang sebagai bagian dari } \\
\text { pembelajaran, dan biasanya dilakukan pada } \\
\text { akhir pembelajaran dengan cara testing. }\end{array}$ & $\begin{array}{l}\text { 5.pengukuran proses dan hasil belajar } \\
\text { siswa terjalin di dalam kesatuan kegiatan } \\
\text { pembelajaran, dengan cara guru mengamati } \\
\text { hal-hal yang sedang dilakukan siswa, serta } \\
\text { melalui tugas-tugas pekerjaan. }\end{array}$ \\
\hline $\begin{array}{l}\text { 6.Siswa-siswi biasanya bekerja sendiri- } \\
\text { sendiri, tanpa ada grup proses dalam belajar. }\end{array}$ & $\begin{array}{l}\text { 6. siswa-siswi banyak belajar dan bekerja } \\
\text { di dalam grup proses. }\end{array}$ \\
\hline
\end{tabular}


Berikut ini akan dikemukakan ciri-ciri pembelajaran yang konstruktivis menurut beberapa literatur yaitu:

a. Pengetahuan dibangun berdasarkan pengalaman atau pengetahuan yang telah ada sebelumnya.

b. Belajar adalah merupakan penafsiran personal tentang dunia.

c. Belajar merupakan proses yang aktif dimana makna dikembangkan berdasarkan pengalaman.

d. Pengetahuan tumbuh karena adanya perundingan (negosiasi) makna melalui berbagai informasi atau menyepakati suatu pandangan dalam berinteraksi atau bekerja sama dengan orang lain.

e. Belajar harus disituasikan dalam latar (setting) yang realistik, penilaian harus terintegrasi dengan tugas dan bukan merupakan kegiatan yang terpisah. (Yuleilawati, 2004 :54).

1. Metode yang Mengajar Guru dalam Pendekatan Teori Konstruktivistik

Pada hakikatnya pembelajaran merupakan kegiatan yang dilakukan untuk menciptakan suasana atau memberikan pelayanan agar peserta didik belajar. Dalam menciptakan suasana atau pelayanan, hal yang esensial bagi guru adalah memahami bagaimana murid-muridnya memperoleh pengetahuan dari kegiatan belajarnya. Jika guru dapat memahami proses pemerolehan pengetahuan, maka ia dapat menentukan strategi atau metode-metode pembelajaran yang tepat bagi muridmuridnya.

Terjadinya proses belajar pada murid yang sedang belajar memang sulit untuk diketahui secara kasat mata, karena proses belajar berlangsung secara mental. Namun, dari berbagai hasil penelitian atau percobaan, para ahli psikologi dapat menggambarkan bagaimana proses tersebut berlangsung. Ahli psikologi konstruktivis berpendapat bahwa proses pemerolehan pengetahuan adalah melalui penstrukturan kembali struktur kognitif yang telah dimiliki agar bersesuaian dengan pengetahuan yang akan diperoleh sehingga pengetahuan itu dapat diadaptasi. Dalam proses belajar mengajar diperlukan suatu cara atau metode untuk mencapai tujuan belajar. Menurut Hamalik (2003:2) 
metode mengajar adalah suatu cara, teknik atau langkah-langkah yang akan ditempuh dalam proses belajar mengajar. Sedangkan Roestiyah (2001:1) Metode mengajar adalah teknik penyajian yang dikuasai guru untuk mengajar atau menyajikan bahan pelajaran kepada siswa di dalam kelas agar pelajaran tersebut dapat ditangkap, dipahami dan digunakan oleh siswa dengan baik.

Ada berbagai metode yang dapat digunakan guru dalam kegiatan pembelajaran, diantaranya; ceramah bervariasi, tanya jawab, diskusi, pemberian tugas, bermain peran, karyawisata, inquiry, kerja kelompok, discovery, demonstrasi. Karena keterbatasan kemampuan dan waktu maka tidak akan semua metode dapat digunakan. Namun yang terpenting adalah penggunaan metode harus dikaitkan dengan situasi dan tujuan belajar yang hendak dicapai dan ditekankan kepada keaktifan siswa dalam membangun pengetahuan. Penjelasan metode-metode tersebut adalah sebagai berikut:

a. Tanya Jawab (Questioning)

Bertanya (questioning) merupakan strategi atau metode utama lainya dalam pendekatan konstruktivisme untuk mengukur sejauh mana siswa dapat mengenali konsep-konsep pada topik pelajaran yang akan dipelajari. Bertanya dalam sebuah pembelajaran dipandang sebagai kegiatan guru untuk mendorong, membimbing, dan menilai kemampuan berpikir siswa. Dalam pembelajaran yang berbasis inquiry, kegiatan bertanya merupakan bagian yang sangat penting untuk menggali informasi, mengkonfirmasikan hal-hal yang sudah diketahui, serta mengarahkan perhatian pada hal-hal yang belum diketahuinya.

Kegiatan bertanya sangat berguna dalam pembelajaran yang produktif seperti dikemukakan Nurhadi (2003: 14) berikut ini:

1) menggali informasi, baik administrasi maupun akademis

2) mengecek pemahaman siswa

3) membangkitkan respon kepada siswa

4) mengetahui sejauh mana keinginan siswa 
5) mengetahui hal-hal yang sudah diketahui siswa

6) memfokuskan perhatian siswa pada sesuatu yang dikehendaki gur

7) membangkitkan lebih banyak lagi pertanyaan dari siswa

8) menyegarkan kembali pengetahuan siswa

b. Penyelidikan (Inquiry)

Pengetahuan dan keterampilan yang diperoleh siswa diharapkan sebagai hasil penyelidikan sampai kepada menemukan sendiri bukan hasil mengingat seperangkat fakta, guru harus berusaha selalu merancang kegiatan yang merujuk pada kegiatan menemukan untuk berbagai materi yang diajarkan. Metode inkuiri dalam proses pembelajaran lebih bersifat student centered. Dalampembelajaran seorang guru hendaknya dapat mengajarkan bagaimana siswa dapat membelajarkan dirinya, karena siswa yang lebih banyak melakukan kegiatan pembelajaran. Belajar dengan metode inkuiri pada dasarnya adalah cara siswa untuk menemukan sendiri pengetahuannya.

Penggunaan metode inkuiri oleh guru akan mengurangi aktivitas guru di kelas dalam arti tidak terlalu banyak bicara, karena aktivitas lebih banyak dilakukan oleh siswa. Guru tidak lagi berperan sebagai pemberi pengetahuan melainkan menyiapkan situasi yang menggiring siswa untuk bertanya, mengamati, menemukan fakta, konsep, menganalisis data dan mengusahakan kemungkinankemungkinan jawaban dari suatu masalah. Inkuiri memberikan perhatian dalam mendorong, siswa menyelidiki secara independen, dalam suatu cara yang teratur. Melalui Inkuiri, siswa bertanya memperoleh dan mengolah data secara logis sehingga mereka dapat mengembangkan strategi intelektual secara umum yang mereka gunakan untuk mendapatkan jawaban atas pertanyaan itu. Belajar dengan melakukan inkuiri pada dasarnya adalah cara siswa untuk "menemukan sendiri", dan karena itu Bruner menyebutnya sebagai discovery. 
Strategi mengajar dengan model inkuiri ini menempatkan siswa tidak hanya dalam posisi mendengarkan, akan tetapi siswa melibatkannya dalam pencarian intelektual yang aktif, pencarian dengan memanipulasi data yang dikumpulkan berdasarkan pengamatan dan pengamalannya sendiri, atau oleh orang lain, untuk dipahami dan dibermaknakan (Wiriaatmadja, 2002:137).

c. Komunitas Belajar (Learning Community)

Komunitas belajar atau belajar kelompok adalah pembelajaran dengan bekerjanya sejumlah siswa yang sudah terbagi kedalam kelompok-kelompok kecil untuk mencapai tujuan tertentu secara bersama-sama (Moejiono,1991/1992:60). Pengembangan pembelajaran dalam kelompok dapat menumbuhkan suasana memelihara disiplin diri, dan kesepakatan berperilaku. Melalui kegiatan kelompok terjadi kerja sama antar siswa, juga dengan guru yang bersifat terbuka. Belajar berkelompok dapat dijadikan arena persaingan sehat, dan dapat pulameningkatkan motivasi belajar para anggota kelompok.Dengan pendekatan konstruktivisme, guru melaksanakan pembelajaran dalam kelompok-kelompok belajar.Siswa dibagi menjadi beberapa kelompok yang anggotanya heterogen.Kelompok siswa bisa sangat bervariasi bentuknya, baik anggotanya maupun jumlahnya.Menurut Slavin (1995:4-5) "kelompok yang efektif terdiri dari empat sampai enam orang, dengan struktur kelompok yang bersifat heterogen".

Pembelajaran dengan konsep komunitas belajar dapat berlangsung apabila ada komunikasi dua arah.Siswa yang terlibat dalam kegiatan komunitas belajar memberi informasi yang diperlukan oleh teman bicaranya dan sekaligus memintainformasi juga yang diperlukan teman belajarnya. Kegiatan beIajar ini dapat terjadi apabila tidak ada pihak yang dominan dalam berkomunikasi, tidak ada pihak yang merasa segan untuk bertanya, tidak ada pihak yang menganggap paling tahu, semua pihak mau saling mendengarkan, pembelajaran dengan teknik komunitas belajar ini 
sangat membantu pembelajaran di kelas.Untuk pelaksanaan metodemetode tersebut berpedoman kepada langkah-langkah yang ditentukan dalam waktu perencanaan. Langkah-langkah pelaksanaannya dapat dilakukan sebagai berikut :

Langkah pertama,siswa didorong dan diberi motivasi agar mengemukakan pengetahuan awalnya tentang konsep dari pokok bahasan atau sub pokok bahasan yang akan dibahas. Guru memancing dengan memberikan pertanyaan-pertanyaan problematik tentang fenomena-fenomena yang sering ditemui sehari-hari dengan mengaitkan konsep yang akan dibahas. Siswa di beri kesempatan untuk mengkomunikasikan, mengilustrasikan pemahamannya tentang konsep itu. Pada langkah ini penggunaan metode tanya jawab sangat diperlukan antara siswa dengan guru, siswa dengan siswa yang difasilitasi oleh guru.

Langkah kedua, siswa diberi kesempatan untuk menyelidiki dan menemukan konsep-konsep dan permasalahan-permasalahan melalui pengumpulan dan pengorganisasian dan penginterpretasian data dalam suatu kegiatan yang telah dirancang guru.Pada tahap ini guru menggunakan metode inquiry. Secara bekerja kelompok siswa membahas kemudian mendiskusikan temuannya dengan kelompokkelompok lain. Secara keseluruhan tahap ini akanmemenuhi rasa keingintahuan siswatentang topik pelajaran yang dibahas pada saat itu.

Langkah ketiga, siswa memberikan penjelasan dan solusi yang didasarkan pada observasinya ditambah dengan penjelasanpenjelasan guru untuk menguatkan pengetehuan siswa yang telah mereka bangun, maka siswa membangun pengetahuan dan pemahaman baru tentang konsep yang sedang dipelajari. Hal ini menjadikan siswa tidak ragu-ragu lagi tentang konsepsinya.

Langkah terakhir, guru berusaha menciptakan iklim pembelajaran yang memungkinkan siswa dapat mengaplikasikan pemahaman konsepnya tentang topik pelajaran saat itu. 
Journal Indonesian Language Education and Literature Vol.1, No. 2, 2016

http://www.syekhnurjati.ac.id/jurnal/index.php/jeill/

\section{B. Metode Penelitian}

Penelitian ini merupakan penelitian deskriptif analisis. Tempat penelitian di kelas intensif Bahasa Arab IAIN Syekh Nurjati Cirebon dengan populasi 600 mahasiswa sedangkan sampelnya 60 mahasiswa. Data diperoleh melalui observasi dan wawancara selama 3 kali pertemuan. Validitas data dengan menggunakan triangulasi metode dan sumber data. Teknik analisis data menggunakan deskriptif analitik.

\section{Hasil dan Pembahasan}

Kelompok 28 dibimbing oleh pengajar bahasa Arab yang dipanggil Pak Habib. Pengajar bahasa Arab pada prosesnya menggunakan metode inquiry, tanya jawab, dan kelompok.

Metode inquiry dan tanya jawab diterapkan oleh pengajar ketika membacakan cerita dalam bahasa Arab. Pengajar menekankan pada kata-kata yang menjadi tema pembicaraan pada saat pembelajaran. Kemudian menanyakan arti kata yang ditekankan kepada siswa. Bila siswa menemukannya, pembacaan cerita dilanjutkan. Namun jika siswa tidak menemukannya, pengajar akan memberikan clue (petunjuk) berupa kalimat dalam bahasa Arab agar siswa dapat menemukannya.

Metode kelompok diterapkan pengajar ketika mempraktikan khiwar atau percakapan yang tertera dalam buku paket. Khiwar dipraktikan berkelompok secara bergantian. Metode kelompok juga digunakan ketika mengartikan sebuah teks sehingga siswa dalam kelompok dapat bertukar pikiran.

Sehingga pembelajaran bahasa Arab di kelompok 28 Program Intensifikasi Bahasa Arab IAIN Syekh Nurjati menerapkan teori kontruktivistik.

\section{Simpulan}

Pengajar di kelompok 28 Program Intensifikasi Bahasa Arab menggunakan metode inquiry, tanya jawab, dan kelompok. Sehingga teori 
konstruktivistik diterapkan secara keseluruhan pada pembelajaran bahasa Arab di kelompok 28.

\section{Daftar Pustaka}

Haryanto. 2014.

http://staff.uny.ac.id/sites/default/files/131656343/TEORI\%20KONSTRUK TIVISTIK.pdf. Diakses tanggal 16 Februari 2016 Pukul 14.50

Lamijan. $2015 . \quad$ Konstruktivisme dalam Pembelajaran. http://umk.ac.id/files/2.04.\%20Konstruktivisme\%20dlm\%20Pembelajaran\% 20-LAM.ppt Diakses tanggal 16 Februari 2016 Pukul 15.02

Riantinas. 2012. Teori Belajar Konstruktivisme. http://riantinas.blogspot.co.id/2012/06/teori-

belajarkonstruktivisme.htmldiakses tanggal 23 Februari 2016 Pukul 15.12

Siregar, Evelin dan Nara Hartini. 2011. Teori Belajar dan Pembelajaran. Bogor: Ghalia Indonesia.

Sumiarni, Hanin. 2014. Pembelajaran Bahasa Arab bagi Mahasiswa Pemula di Pusat Bahasa dan Budaya (PBB) IAIN Syekh Nurjati Cirebon (Problematika dan Solusinya). Holistik Volume 15 Nomor 01, 2014 diunduh dari http://www.syekhnurjati.ac.id/jurnal/index.php/holistik/article/viewfile/432/ 279/ pada 17 Mei 2015 Pukul 15.00 